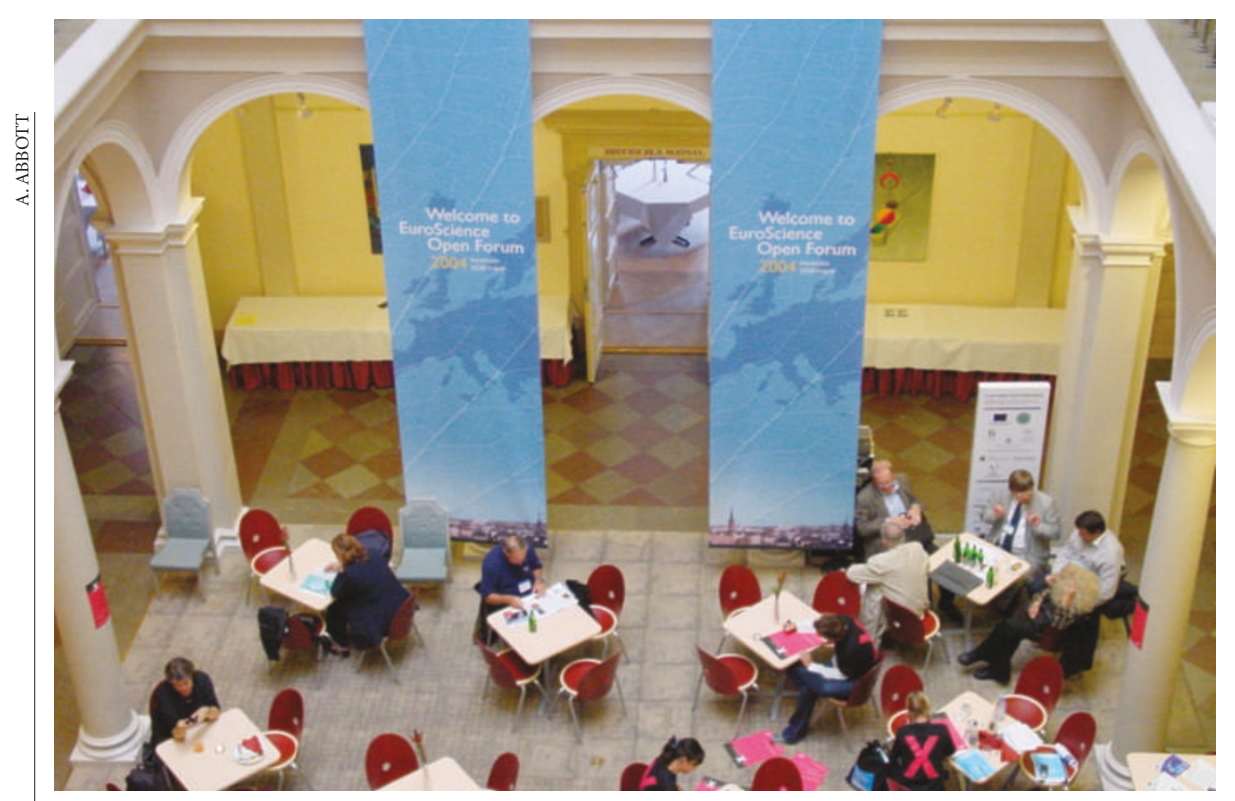

Café society: the EuroScience Open Forum won participants over with its relaxed atmosphere.

\title{
Organizers claim success for Stockholm science jamboree
}

\section{Alison Abbott, Stockholm}

Sceptics said it couldn't work. The very time and place of the first EuroScience meeting bringing together scientists, journalists and the public to celebrate science - à la the annual AAAS meeting in the United States - spoke against it.

It is difficult enough to get European researchers, who will happily attend US meetings, to come together on home turf. And on a continent where August holidays are sacred, who would instead visit one of Europe's most expensive cities for an untested meeting?

But 1,800 people came to the EuroScience Open Forum (ESOF) meeting in Stockholm, Sweden, from 25-28 August, exceeding the 1,500 expected. And they soon found their irritation at some teething problems waning in the feel-good atmosphere that ESOF generated - aided by its location at the heart of the historic city. "Being in the city is fundamental for this type of conference," says Clive Cookson, science editor of the Londonbased Financial Times.

ESOF 2004 was organized by EuroScience, founded in 1997 to promote science and its public discussion. The meeting's sponsors, including Nature, rather than its participants, met most costs. Sponsors expressed satisfaction, and the two German groups who contributed most, the Robert Bosch Foundation and the Stifterverband, a donors' association for the sciences and humanities, are supporting the next meeting, planned for Munich in July 2006.

A third of participants came from Sweden and more than 50 flew in from the United States, with 68 countries represented in all. There were 350 journalists.
Alan Leshner, chief executive of the AAAS, formerly the American Association for the Advancement of Science, took the opportunity to announce that the body will in future use only its acronym, to emphasize its global reach.

Though many attendees complained of too many sessions on media and policy and too few on science, some of the scientific sessions were novel and successful. Rainer Goebel from the University of Maastricht in the Netherlands, for example, made his audience gasp when he described his studies of people controlling a computer game with their thoughts via brain-imaging machines.

Another success was the Science in the City programme, which brought theatre, films, exhibitions and other events to venues across Stockholm. The Amazing Profmobile, a rickshaw, took scientists to address surprised shoppers and pedestrians. Rolf Tarrach, a physicist from the University of Barcelona, rushed gleefully between theatre and scientific sessions. The programme was a "fantastic European experience which resonates with this historic city", he says.

There were a few teething troubles. Journalists complained that talks lacked written summaries. Some of the presentations were too technical for their audience. And few students and younger researchers were present.

There will be better support next time for journalists, and more training of speakers, says ESOF 2004 organizer Carl Sundberg, a physiologist at the Karolinska Institute in Stockholm who is also on the steering committee for ESOF 2006. "And we'll look more imaginatively at participation fees, to ensure there is no barrier to students," he says.
Wildlife campaigners fight planned site for Scripps Florida

Rex Dalton, San Diego

An environmental backlash is threatening to delay the Scripps Research Institute's plans to build a huge research and biotechnology complex near Palm Beach in Florida.

Scripps Florida is to be built on a 780-hectare site near a wildlife refuge. But criticism from environmental groups has made some local politicians change their minds about the site. State and county officials plan to invest $\$ 770$ million in Scripps Florida (see Nature 426, 4; 2003).

Palm Beach County last month asked Scripps, based in La Jolla, California, to consider two other sites, both of which are less environmentally sensitive. But the sites are smaller, at less than $\mathbf{3 5 0}$ hectares, and might curtail the institute's industrial growth.

Scripps' board will meet privately on 13 September to consider its options. Although it could agree to one of the new sites, under the present contract signed by the county, it can demand permits for the original property by next January. Palm Beach County council will meet on 14 September to consider its response to Scripps' decision.

If Scripps' board pushes for the original site, it faces an environmental fight in the courts, which critics of the project say could hold it up for years.

It is also possible that such a course would embolden local opposition to plans laid by Palm Beach County officials, who say they intend to spend $\$ 400$ million on Scripps Florida. State governor Jeb Bush, the president's brother, has championed Florida's \$370million state contribution to the project.

Already, several environmental groups, including the Florida Wildlife Federation and the National Audubon Society, are challenging the original site's water permits, which could delay the process several months. Called Mecca Farms, the site is next to the J. W. Corbett Wildlife Refuge, in a region crossed by waterways that feed the Everglades.

Chemist Richard Lerner, president of Scripps and mastermind of the Florida project, says that he won't make a site recommendation to his board. "There are pros and cons to every side," he says. Scripps Florida is already hiring scientists who are setting up labs in temporary facilities in Palm Beach County. "The scientists don't care much about which site is selected," Lerner says. 